\title{
Peer review reviewed
}

\author{
The US research community is responding vigorously to calls to help change the system of grant \\ assessment at the National Institutes of Health. A radical transformation is urgently needed.
}

1 he peer-review system used by the $\$ 29$-billion National Institutes of Health (NIH) is more than half-a-century old, and is showing its age. It has become stretched by the breadth of today's science, in which inter- and multidisciplinary grant applications are common, and by the sheer volume of submissions in an era in which one-grant labs have gone the way of the dinosaur.

Twenty years ago, some 1,800 reviewers judged grant applications for the NIH's Center for Scientific Review, which oversees the lion's share of the agency's peer review; today, that number is more than 18,000 . Increasingly, ad hoc and junior reviewers have been called into service - the former to provide expertise on complex multidisciplinary grants, the latter because of volume and because senior scientists feel that they have already paid their dues with earlier service.

Complicating this unwieldy situation, the current NIH funding freeze has made funding committees conservative to the point that an application must be almost perfect to be funded on its first submission. A searching assessment of how the system can be reshaped and improved is essential. The Center for Scientific Review has already sought feedback through a series of field-specific community sessions and has tested some changes, such as shorter grant-review cycles and a more electronic grant-evaluation process.

Separately, NIH director Elias Zerhouni in June launched a bid to restructure peer review at the NIH to reflect foreseeable needs. An internal panel of senior NIH officials and an illustrious working group of non-NIH scientists jointly face a deceptively simple challenge: to ensure that the agency funds the best science by the best scientists with the lightest administrative burden.

Ideas were solicited this summer at a packed meeting of scientificsociety leaders in Washington DC. More researchers' opinions are being gathered at meetings in Chicago, New York and San Francisco this month and next. Electronic comments were invited over a twomonth period that ended last Friday. Judging by the 2,000 opinions submitted, the extramural community has plenty to say on the matter.
The two groups aim to have concrete recommendations by early this winter, with the goal of launching pilot projects as soon as next spring. They have asked for 'creative' and even 'radical' ideas, intending to act not on the most popular suggestions but on the best ones.

Still, good ideas have emerged in the 'popular' category: there are strong arguments to be made for shortened grant applications and for regular 'bridge' funding to see investigators through gaps between grants. It is also important to ensure that senior, accomplished scientists serve on study sections. There is simply no replacement for the brains, experience, insight and judgement that they bring to bear on applications.
"The NIH needs to fund the best science by the best scientists with the lightest administrative burden."

To this end, NIH grantees should be required to serve on study sections if the agency asks for their help - with due provision to ensure that they are not overburdened, and perhaps also a reward in the form of increased funds for their own grants. This would ensure that the best scientists are recruited onto study sections, and that senior scientists are brought back into the system.

A proposal put forward by the Association of American Medical Colleges, and probably others, would allow individual scientists to have only one application of a given kind in the system at any one time. Multiple grants could still be held by one scientist, but he or she could have only one application per mechanism under review. This would compel self-selection of the best proposals by scientists upstream of the review process. To be workable, this would necessitate a funding cycle that lasts at most six months rather than the current ten. But that compression is highly desirable in any case and has already been accomplished in pilot trials.

Such an approach can only help the most creative scientists by stemming the current deluge of applications. It's a radical idea but, for that reason at least, an excellent one.

\section{Meeting obligations}

\section{Climate change should take ever-increasing priority in the Asia-Pacific region.}

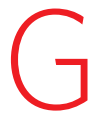
atherings of world leaders are never easy events, and last week's Asia-Pacific Economic Cooperation (APEC) forum in Sydney, Australia, was no exception. The United States and South Korea, for example, shared some awkward moments over whether the Korean War should officially be declared over; and environmental activists complained that not enough was done to advance one of the meeting's key issues: climate change.
Yet the very fact that climate change was on the APEC agenda was a start. It was put there by one of the environmentalists' greatest foes, Australian prime minister John Howard - a man who has consistently opposed the notion of mandatory emissions cuts. Unsurprisingly, the statement signed by the 21 APEC leaders was vague, calling for just two specific actions: an additional 20 million hectares of forest in the region by 2020 , and a $25 \%$ reduction in energy intensity - the amount of greenhouse gases released per dollar of gross domestic product - by 2030. And there are no penalties set out for not meeting these 'aspirational' goals.

It is encouraging that the APEC leaders have issued a climate consensus, however weak. Such discussions, after all, emphasize the increasing importance that the Asia-Pacific region plays in the 
climate-change arena. Too often the United States and Europe are portrayed as the main players on climate issues, while Asian countries feature mainly when others excuse their alleged inaction by pointing fingers at the booming economies of China and India, who under the Kyoto Protocol on climate change are not bound to reduce their emissions. But China is moving ahead on its own - President $\mathrm{Hu}$ Jintao has regularly spoken about the importance of climate change as a global issue, and last week his country announced plans to get $15 \%$ of its energy from renewable sources by 2020 .

Political changes in some of the countries holding out on climate change may help facilitate Asian action. Howard is expected to call elections for this winter, and he is running far behind his opposition in the polls. George W. Bush will be out as of January 2009, and nearly all of the leading presidential candidates could provide the US leadership on climate change that has been so sorely lacking.

So what next? Yet more meetings. Earlier this week a number of the Asian players, including Australia, China, Indonesia and India, joined the 'Gleneagles dialogue' in Berlin, in which energy and environment ministers discuss clean-energy goals. This is but a minor step on the path to a real emissions policy; another such sidestep will come at the end of this month, when Bush launches discussions in Washington DC on what to do about climate-change targets when the Kyoto agreement expires in 2012. As the United States has not ratified Kyoto, this is likely to be something of a distraction.

Stakeholders should instead focus their efforts on the talks in early December in Bali, Indonesia, which will include all the parties to Kyoto. This meeting, run by the United Nations Framework Convention on Climate Change, embodies the de facto international framework for discussing climate change, and as such is the outlet best suited for constructing emissions commitments.

International negotiators must work together towards a clear and consistent discussion at all these meetings. Representatives from the Asian bloc should continue to keep climate change as a high priority, and make more aggressive moves towards implementing real targets for emissions cuts at the Bali meeting. Asia has both the economic clout and the incentive to be a world leader in climate change.

\section{Turkey's transformation}

\section{A European vision and a commitment to openness will foster good science.}

T urkish scientists have never had it so good, thanks to their country's efforts to align its laws and policies to those required for membership of the European Union (EU). In a bid to create a science and higher-education landscape that matches the EU norm, Turkey has more than doubled its research spending in the past five years, and is half way to its goal of spending $2 \%$ of its gross domestic product on research by 2010. It has refined its peer-review procedures for research grants to improve fairness and transparency, and is actively promoting research in industry. The country's best scientists say that for the first time it is now possible to get grants of a decent size - even up to hundreds of thousands of dollars — for a strong basic-research project.

To be able to spend the new money as wisely as possible, Turkey needs to expand, and rejuvenate, its relatively small community of scientists. Plans are in motion, thanks again to the country's westward focus. Nineteen new universities will be founded in the next few years. Special grants to allow young scientists to set up independent research labs in universities have been established. And with so much more money available for research, Turkish scientists are now starting to come home from abroad.

To encourage individual scientists to become more active, Tubitak, the main research agency - and sometimes the universities themselves - top up the personal salaries of grant-winners and offer financial incentives for publication in international journals. This has helped push Turkey up from 27 to 19 in the world rank of science publication rates since 1997.

But impact, as measured by citations per paper, has increased only slightly in that time. And Turkey's commitment wavered last year after its scientists won few grants from the sixth EU Framework programme
(2002-06) - the first to which it contributed funds. It was persuaded only with difficulty to join the seventh programme. Finally accepting that its scientists would only improve in the short term through continued close contact and competition with their EU colleagues, the Turkish government signed on the dotted line in June.

All seems to be set fair for scientific growth - provided Turkish politics remain stable. This seems likely, despite alarm bells being sounded by many inside and outside the country following the recent re-election of a mildly Islamic government, headed by a new religiously minded president. The old-guard academic élite, in particular, foresee dire consequences arising from the almost certain relaxation of rules that ban headscarves in government-funded institutions, including universities. What they fear most is an 'Islamization' of politics, and the discarding of the secular constitution written by Mustafa Kemal Atatürk when he founded the Republic of Turkey in 1923. The headscarf is a powerful symbol of the tensions between ardent secularists and the religious - tensions that are evident in all areas of public life.

But more scientists are coming to accept that the right to wear a headscarf in an educational establishment may not, after all, be the thin end of an extremist wedge. Secularism's deep roots won't be overturned so easily in a country where the majority of the electorate, who happen to be religious, are becoming materially wealthier under Western aspirations. There is no room for complacency, however. Frictions closer to the country's eastern border with Iran - where a university rector recently fell foul of religious groups and ended up in jail - are less easy to control. Nationalism is also a threat to stability; an insidious law criminalizing 'insulting Turkishness', which has been used on occasion to silence public opposition, needs to be repealed.

Science was the first focus of negotiations in Turkey's bid for EU membership - and had been so well prepared that the chapter could be closed in only nine months. The nation's European ambitions are also likely to provide an incentive for repeal of the nationalist law. Whether or not Turkey will become the EU's first Muslim member state is hard to predict, but the benefits of that ambition for science and more are clear. 